\title{
Acetylene Reduction by Klebsiella pneumoniae in Air Related to Colony Dimorphism on Low Fixed Nitrogen
}

\author{
By SUSAN HILL \\ Agricultural Research Council, Unit of Nitrogen Fixation, \\ University of Sussex, Falmer, Brighton BNI $9 Q J$
}

(Received 20 May 1975)

\section{INTRODUCTION}

Until recently it was believed that Klebsiella pneumoniae fixed nitrogen only under anaerobic conditions (see Postgate, 1971). However, Klucus (1972) showed that a species of Klebsiella produced active nitrogenase in the presence of $\mathrm{O}_{2}$ in a chemostat culture provided that the medium contained yeast extract ( $\mathrm{g} / \mathrm{l}$ ) as a fixed $\mathrm{N}$ source and the dissolved oxygen tension was at $10 \mathrm{mmHg}$ or below. Klucus (1972) suggested that the tolerance of nitrogenase activity to $\mathrm{O}_{2}$ arose because of a high respiratory rate at low dissolved oxygen tension (Harrison \& Pirt, 1967; Harrison \& Loveless, 197I) which could maintain the local oxygen tension at a very low level, although he did not measure respiratory rates. The obligate aerobe Derxia gummosa is particularly sensitive to $\mathrm{O}_{2}$ when fixing $\mathrm{N}_{2}$ (Hill \& Postgate, I969; Hill, I97I) and shows colony dimorphism on $\mathrm{N}$-free media in air (Jensen, Petersen, De \& Bhattacharya, 1960). Only the 'massive' colonies which develop among many 'thin' whitish colonies fix nitrogen (Jensen et al. 1960) or reduce acetylene (Hill, 197I). The numbers of colonies developing into the 'massive',type could be increased by either adding fixed nitrogen (Tchan \& Jensen, 1963) or lowering the atmospheric oxygen concentration (Hill, 197I). Colony dimorphism probably arises in air because nitrogen fixation and subsequent growth to the 'massive' colony type takes place only where the local oxygen tension can become depressed (Hill, I97I). A methane-oxidizing bacterium also showed dimorphism during growth on a $\mathrm{N}$-free medium in air (De Bont \& Mulder, 1974). The present work demonstrates that $K$. pneumoniae, although probably more sensitive to $\mathrm{O}_{2}$ when fixing $\mathrm{N}_{2}$ than D. gummosa, also shows colony dimorphism associated with $\mathrm{N}_{2}$ fixation when incubated in air if the medium is supplemented with low levels of fixed nitrogen.

\section{METHODS}

Organism. Klebsiella pneumoniae M5al, a gift from Professor P. W. Wilson, was maintained at $20{ }^{\circ} \mathrm{C}$ in air on $2 \%(\mathrm{w} / \mathrm{v})$ nutrient agar slopes and subcultured monthly.

Media. The $\mathrm{N}$-free medium contained per litre: $\mathrm{I} 5 \mathrm{~g}$ glucose, $\mathrm{I} 2.06 \mathrm{~g} \mathrm{~K}_{2} \mathrm{HPO}_{4}, 3.4 \mathrm{~g}$ $\mathrm{KH}_{2} \mathrm{PO}_{4}, 26 \mathrm{mg} \mathrm{CaCl}{ }_{2} .2 \mathrm{H}_{2} \mathrm{O}, 30 \mathrm{mg} \mathrm{MgSO}_{4}, 0.3 \mathrm{mg} \mathrm{MnSO}_{4}, 36 \mathrm{mg}$ ferric citrate, $7.6 \mathrm{mg}$ $\mathrm{Na}_{2} \mathrm{MoO}_{4} \cdot 2 \mathrm{H}_{2} \mathrm{O},{ }^{\mathrm{r}} \mathrm{IO} \mu \mathrm{g} p$-aminobenzoic acid, $5 \mu \mathrm{g}$ biotin, I5 g agar (Bacto-agar, Difco), and, when required, from $2 \mathrm{mg}$ to $2 \mathrm{~g}$ vitamin-free Casamino acids (Difco). The two vitamins are not in fact required by $K$. pneumoniae.

Incubation of plates under various atmospheric oxygen concentrations. Cultures inoculated on to solid media were incubated at $30^{\circ} \mathrm{C}$ under atmospheric oxygen concentrations below $0.2 \mathrm{~atm}$ in nylon bags as described by Hill (1973).

Acetylene reduction. A portion (approximately $2 \mathrm{~cm}^{2}$ ) bearing colonies was cut from cultures grown on solid media in Petri dishes and placed in a serum bottle $(7.5 \mathrm{ml})$. The bottle 

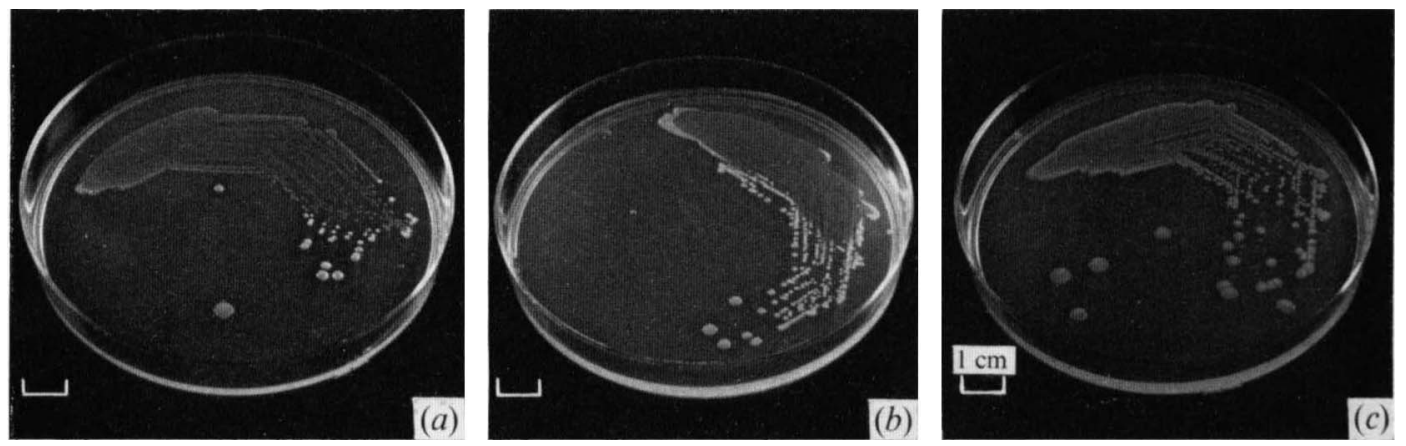

Fig. I. Colony morphology of $K$. pneumoniae on the medium containing $200 \mu \mathrm{g}$ Casamino acids $/ \mathrm{ml}$ after 8 days incubation at $30{ }^{\circ} \mathrm{C}$ in (a) air, (b) 0.25 atm air +0.74 atm $\mathrm{N}_{2}+0.01$ atm $\mathrm{CO}_{2}$ or $(c)$ $0.99 \mathrm{~atm} \mathrm{~N}_{2}+0.0$ I atm $\mathrm{CO}_{2}$. A progressively greater proportion of the colonies developed into the large yellowish-brown type than into the small white type when the atmospheric $p \mathrm{O}_{2}$ was lowered.

was gassed with argon and capped with a Suba-Seal closure (William Freeman Ltd, Barnsley, Yorkshire). Oxygen was injected to the required atmospheric $p \mathrm{O}_{2}$, followed by $0.8 \mathrm{ml} \mathrm{C}_{2} \mathrm{H}_{2}$. After each injection the excess gas pressure was released. The bottles were incubated at $30^{\circ} \mathrm{C}$ without shaking and gas samples $(0.5 \mathrm{ml})$, removed for analyses for ethylene by gas chromatography, were replaced by $0.5 \mathrm{ml}$ of the initial gas mixture of $\mathrm{Ar}$ or $\mathrm{Ar}+\mathrm{O}_{2}$. Gas samples for analysis were injected into a Pye 104 chromatograph which was fitted with a flame ionization detector and a $45 \mathrm{~cm}$ column ( $\mathrm{mm}$ internal diameter) filled with either Porapak R or Porapak N (mesh IO0 to I 20), and maintained at $37^{\circ} \mathrm{C}$ with $\mathrm{N}_{2}$ as carrier gas flowing at $7 \mathrm{ml} / \mathrm{min}$. Ethylene peak heights were recorded and compared with standards.

\section{RESULTS}

Nitrogen-fixing cultures of $K$. pneumoniae were grown in liquid $\mathrm{N}$-free medium either anaerobically in batch culture (medium contained $\mathrm{I} \%, \mathrm{w} / \mathrm{v}$, glucose) or in an $\mathrm{O}_{2}$-limited chemostat culture (medium contained $0.5 \%$ glucose) at $30{ }^{\circ} \mathrm{C}$, and organisms were inoculated on to the solid $\mathrm{N}$-free medium containing $0,20 \mu \mathrm{g}, 200 \mu \mathrm{g}$, or $2 \mathrm{mg}$ Casamino acids $/ \mathrm{ml}$. After 7 days in air at $30^{\circ} \mathrm{C}$, only very small white colonies were present with o or $20 \mu \mathrm{g}$ Casamino acids $/ \mathrm{ml}$; these developed into large colonies when the plates were transferred to anaerobic conditions. With $2 \mathrm{mg}$ Casamino acids $/ \mathrm{ml}$ in air, all colonies were large and brown. These colonies reduced $\mathrm{C}_{2} \mathrm{H}_{2}$ when tested anaerobically or under $0.2 \mathrm{~atm} \mathrm{O}_{2}$. With $200 \mu \mathrm{g}$ Casamino acids $/ \mathrm{ml}$ in air, most of the colonies were small and white but a few, in the sparsely inoculated areas, were large and yellowish brown (see Fig. I $a$ ). Approximately similar areas of each colony type, grown for 8 days, were tested for $\mathrm{C}_{2} \mathrm{H}_{2}$ reduction. Blocks carrying the large, yellowish-brown colonies produced 62 to $129 \mathrm{nmol}$ ethylene in $210 \mathrm{~min}$ when tested anaerobically, in 0.05 or 0.2 atm $\mathrm{O}_{2}$. Those with the small white colonies did not produce ethylene. Ethylene production by the large yellowish-brown colonies was progressive and was not observed in the absence of $\mathrm{C}_{2} \mathrm{H}_{2}$. When the two colony types were separately inoculated on to the medium containing $200 \mu \mathrm{g}$ Casamino acids $/ \mathrm{ml}$ and incubated in air both subcultures showed a similar distribution of colony type. A progressively greater proportion of the large to the small colonies developed when cultures on this medium were incubated for 8 days in air, or in air diluted with different amounts of $\mathrm{N}_{2}+\mathrm{CO}_{2}$ (see Fig. I). 


\section{DISCUSSION}

The two colony types were not genetically different since colony dimorphism was observed when either colony type was used as parent, the relative numbers of either type could be altered by changing the amount of fixed nitrogen or by altering the atmospheric $p \mathrm{O}_{2}$, and the small colonies developed into the large colonies when the atmospheric $p \mathrm{O}_{2}$ was lowered. With $200 \mu \mathrm{g}$ Casamino acids/ml, colony dimorphism in air was similar to that of $D$. gummosa (Jensen et al. 1960; Hill, 197I). With both $D$. gummosa and $K$. pneumoniae, large $\mathrm{N}_{2}$-fixing colonies probably develop predominantly in the sparsely inoculated areas, because sufficient fixed nitrogen diffuses from surrounding sterile areas to allow growth and accompanying respiratory activity to lower the local oxygen tension. Only then can $\mathrm{N}_{2}$ fixation, and hence further growth, occur. In D. gummosa 'massive' colonies developed occasionally in densely inoculated areas where, it was suggested, competition for $\mathrm{O}_{2}$ resulted in a low local oxygen tension (Hill, I97I). Similarly, a large colony of $K$. pneumoniae sometimes developed on the edge of a densely inoculated area (see Fig. $\mathrm{I}$ a); this area reduced $\mathrm{C}_{2} \mathrm{H}_{2}$. Klebsiella pneumoniae formed only small colonies in air on the $\mathrm{N}$-free medium whereas $D$. gummosa under comparable conditions formed occasonal 'massive' colonies, indicating that $K$. pneumoniae is more oxygen-sensitive when fixing $\mathrm{N}_{2}$ than $D$. gummosa.

\section{REFERENCES}

DE Bont, J. A. M. \& Mulder, E. G. (1974). Nitrogen fixation and co-oxidation of ethlyene by a methaneutilizing bacterium. Journal of General Microbiology 83, I I 3-I 2 I.

HARRISON, D. E. F. \& Loveless, J. E. (I97I). The effect of growth conditions on respiratory activity and growth efficiency in facultative anaerobes grown in chemostat culture. Journal of General Microbiology 68, 35-43.

Harrison, D. E. F. \& PIRT, J. S. (I967). The influence of dissolved oxygen concentration on the respiration and glucose metabolism of Klebsiella aerogenes during growth. Journal of General Microbiology 46, I93-2II.

HiLl, S. (197I). Influence of oxygen concentration on the colony type of Derxia gummosa grown on nitrogen-free media. Journal of General Microbiology 67, 77-83.

HILL, S. (I973). Method for exposing bacterial cultures on solid media to a defined gas mixture using nylon bags. Laboratory Practice 22, 193.

Hill, S. \& Postgate, J. R. (I969). Failure of putative nitrogen-fixing bacteria to fix nitrogen. Journal of General Microbiology 58, 277-285.

Jensen, H. L., Petersen, E. J., De, P. K. \& Bhattacharya, R. (1960). A new nitrogen-fixing bacterium: Derxia gummosa nov.gen. nov.spec. Archiv für Mikrobiologie 36, 182-195.

KLUCUS, R. (1972). Nitrogen fixation by Klebsiella grown in the presence of oxygen. Canadian Journal of Microbiology 18, I845-1850.

Postgate, J. R. (I97I). Fixation by free-living microbes: physiology. In The Chemistry and Biochemistry of Nitrogen Fixation, pp. 16I-190. Edited by J. R. Postgate. London and New York: Plenum Press.

TCHAN, Y. T. \& JENSEN, H. L. (1963). Studies on nitrogen-fixing bacteria. VIII. Influence of N-content of the media on the N-fixation capacity and colony variation of Derxia gummosa, Jensen et al. 1960. Proceedings of the Linnean Society of New South Wales 88, 379-385. 